\title{
Assessment of new radioimmunoassay kit for determining urinary albumin at low concentrations: comparison with radial immunodiffusion
}

\author{
G F WATTS,* J D M ALBANO, ${ }^{*}$ J E BENNETT,* R W MORRIS, $\dagger$ K M SHAW, \\ A POLAK*
}

From the *Wessex Regional Renal Unit and Portsmouth Hospitals, Portsmouth, Hampshire, and the $\dagger$ Department of Community Medicine, United Medical and Dental Schools of Guy's and St Thomas's Hospitals, London

SUMMARY The assay characteristics of a new radioimmunoassay kit for determining urinary albumin at low concentrations were studied. The sensitivity for urinary albumin was $2 \mathrm{mg} / \mathrm{l}$, the analytical range 2 to $40 \mathrm{mg} / \mathrm{l}$, and interassay coefficient of variation $<12 \%$. In a method comparison study entailing diabetic urine samples covering an albumin concentration of 2 to $150 \mathrm{mg} / 1$ the kit compared adequately with radial immunodiffusion (mean difference between methods = $2 \mathrm{mg} / \mathrm{l}$; residual standard deviation $=4.6 \mathrm{mg} / \mathrm{l})$, absolute variation between methods increasing with the concentration. The kit required much less skill than radial immunodiffusion but its capital and running cost were higher.

Nephropathy is a major cause of death in diabetics. ${ }^{1}$ "Microalbuminuria" defines a raised concentration of urinary albumin undetectable by the Albustix dip test for protein: it has been shown to predict diabetic nephropathy ${ }^{2-4}$ and to be reversible by strict glycaemic control ${ }^{5}$ and treatment of concomitant hypertension. ${ }^{6}$ As a result, there has been an increasing demand from those involved in diabetic care for methods of determining microalbuminuria. The laboratory must meet this demand with assays of sufficient sensitivity, specificity, reliability and practicability, criteria which can at present only be fulfilled by immunochemical methods. In this study we assess the analytical performance and practicability of a new radioimmunoassay kit and compare it with the established single radial immunodiffusion method of Mancini.

\section{Material and methods}

RADIOIMMUNOASSAY KIT

The radioimmunoassay kit (H-ALBUMIN KIT, Metachem Diagnostics Ltd, Northampton, Northamptonshire, United Kingdom) is a liquid phase saturation assay that uses ${ }^{125}$ iodine labelled albumin and antihuman albumin coupling, entailing the use of a polyethylene glycol accelerated second antibody

Accepted for publication 8 May 1986 separation phase. Bound radioactivity is inversely related to the analyte concentration.

Table 1 details the assay protocol, which strictly adhered to the manufacturer's instructions. Standards, controls, and urine samples were vortex mixed with ${ }^{125} \mathrm{I}$-albumin, first antibody, and second antibody in small plastic tubes (LP3, Luckhams Ltd, Burgess Hill, Sussex, United Kingdom) and incubated for one hour at ambient temperature $\left(18-20^{\circ} \mathrm{C}\right)$. Two $\mathrm{ml}$ of polyethylene glycol was then added to the tubes, which were centrifuged at $1500 \times g$ for 10 minutes at ambient temperature in an MSE Coolspin (Fisons Ltd, Crawley, Sussex, United Kingdom). The supernatant was removed by suction and the polyethylene glycol precipitate counted in a 500C Autogamma Counter (Packard Instruments Ltd, Caversham, Berkshire, United Kingdom) set for ${ }^{125}$ I albumin. An albumin standard curve of activity against log concentration was constructed by linear interpolation of data points from which test and control values were derived.

\section{KIT ASSA Y CHAR A CTERISTICS}

Assay characteristics were studied using kits from three separate lot numbers $(01,01 \mathrm{~A}, 5301-\mathrm{AV})$, all assays being performed before the stated expiry date. Sensitivity was expressed as the lowest concentration of urinary albumin in $\mathrm{mg} / \mathrm{l}$ that was consistently distinguishable from blank $(n=20)$. 
Table 1 Protocol for radioimmunoassay kit

\begin{tabular}{|c|c|c|c|c|c|}
\hline Reagent & Total activity & Non-specific binding & Zero standard & Standards 1 to $7^{*}$ & Sample/control \\
\hline $\begin{array}{l}\text { Sample control } \\
\text { Buffer } \\
\text { Standards } 1 \text { to } 7^{*} \\
{ }_{125} \text { I-albumin } \\
\text { First antibody } \\
\text { Second antibody }\end{array}$ & $100 \mu \mathrm{l}$ & $\begin{array}{l}225 \mu \mathrm{l} \\
100 \mu \mathrm{l}\end{array}$ & $\begin{array}{c}25 \mu \mathrm{l} \\
100 \mu \mathrm{l} \\
100 \mu \mathrm{l} \\
100 \mu \mathrm{l}\end{array}$ & $\begin{array}{c}25 \mu \mathrm{l} \\
100 \mu \mathrm{l} \\
100 \mu \mathrm{l} \\
100 \mu \mathrm{l}\end{array}$ & $\begin{array}{l}100 \mu l \\
100 \mu l \\
100 \mu l\end{array}$ \\
\hline
\end{tabular}

*Albumin concentration $=100,50,25,12 \cdot 5,6 \cdot 25,3 \cdot 12,1 \cdot 56 \mathrm{mg} / \mathrm{l}$.

The analytical range corresponded to the concentration range of the calibration curve that gave an interassay coefficient of variation (CV) $<12 \%$ and whose lowest value was the assay sensitivity. Intraassay imprecision was calculated from duplicates covering the analytical range $(n=50)$. Interassay variation was measured using 10 different kits from three separate lot numbers and at five albumin concentrations, covering the assay range stated by the manufacturer-that is, $3-100 \mathrm{mg} / \mathrm{l}$. Recoverability was assessed by adding pure human albumin (Behring Diagnostics, Hoechst United Kingdom Ltd, Hounslow, Middlesex) at five levels to four separate urines and plotting observed against expected albumin concentration.

\section{RADIAL IMMUNODIFFUSION}

The details of this technique were carried out according to the method of Mancini et al. ${ }^{7}$ The satisfactory performance of this assay, as applied to urine albumin estimation, has been documented. ${ }^{8}$

\section{ASSAY PRACTICABILITY}

Table 2 shows the criteria used to assess practicability. Technical skill required was graded as high, average, and low according to the time taken by an unskilled trainee to achieve an interassay CV $<12 \%$. Capital and running costs refer to 1985 prices. Running cost included labour, which was calculated from the hourly rate of pay for a state registered medical laboratory scientific officer working in the NHS in the United Kingdom.

Table 2 Comparison of practicability of radioimmunoassay kit $(K I T)$ and radial immunodiffusion (RID)

\begin{tabular}{lll}
\hline Criterion & $K I T$ & $R I D$ \\
\hline Sample size $(\mu \mathrm{l})$ & 25 & $2 \cdot 5$ \\
Radioactivity/100 tests & $3 \mu \mathrm{Ci}$ & \\
No of reagent additions & 3 & 2 \\
Centrifugation steps & 1 & \\
Technical skill required & Low & High \\
Turnaround time (hours/100 tests) & 4 & 48 \\
Running cost $(f / 100$ tests) & 190 & $14 \cdot 6$ \\
Capital cost $(f)$ & 16000 & 235 \\
\hline
\end{tabular}

\section{METHODS COMPARISON AND STATISTICAL}

ANALYSIS

Urine samples from 64 diabetic patients, covering an albumin concentration range from 0 to $150 \mathrm{mg} / \mathrm{l}$, were assayed by radioimmunoassay and radial immunodiffusion. Where required, urines were diluted into the analytical range of the assay. The kits used were all of the same lot number (01). Albumin concentrations obtained with radioimmunoassay were compared with those obtained by radial immunodiffusion by plotting the differences $(\mathrm{mg} / \mathrm{l})$ between paired samples against the mean of the two values. ${ }^{9}$ Systematic error was evaluated by performing a paired $t$ test on the mean differences $(\mathrm{mg} / \mathrm{l})$ between methods. Random error was assessed as the residual standard deviation using a two way analysis of variance. ${ }^{10}$ As the absolute variation betwee methods increased with albumin concentration sys tematic and random error were assessed for low anch high readings. An arbitrary division was made at $30 \mathrm{mg} / \mathrm{l}$, as a urinary albumin concentration greater than this has been shown to predict diabetic nephropathy. ${ }^{11}$

\section{Results}

KIT ASSAY CHARACTERISTICS (TABLE 3; FIG 1)

The sensitivity of the assay for albumin in urine was $2 \mathrm{mg} / \mathrm{l}$. Recoverability and interassay imprecision are both unsatisfactory above a concentration of about $40 \mathrm{mg} / \mathrm{l}$. The analytical range is thus quoted as 2 to $40 \mathrm{mg} / \mathrm{l}$ over which the intra-assay $\mathrm{CV}=4 \%$.

Table 3 Characteristics of radioimmunoassay kit

\begin{tabular}{lcccc}
\hline & $\begin{array}{l}\text { Mean } \\
(\mathrm{mg} / \mathrm{l})\end{array}$ & $\begin{array}{l}\text { SD } \\
(\mathrm{mg} / \mathrm{l})\end{array}$ & $\begin{array}{l}\text { CV } \\
(\%)\end{array}$ & (n=) \\
\hline Interassay imprecision & 5.4 & 0.3 & 5.2 & 20 \\
$($ kits = 10) & 15.0 & 1.6 & 10.6 & 20 \\
& 22.0 & 2.5 & 11.4 & 20 \\
& 57.3 & 10.5 & 18.4 & 20 \\
& 87.3 & 14.1 & 17.6 & 20 \\
\hline
\end{tabular}

Analytical range $(2-40 \mathrm{mg} / \mathrm{l})$; Sensitivity $(2 \mathrm{mg} / \mathrm{l})(\mathrm{n}=20)$; Intra assay ${ }^{*}$ imprecision $(\mathrm{CV}=4 \%, \mathrm{n}=50)$.

*Calculated from duplicates covering analytical range. 


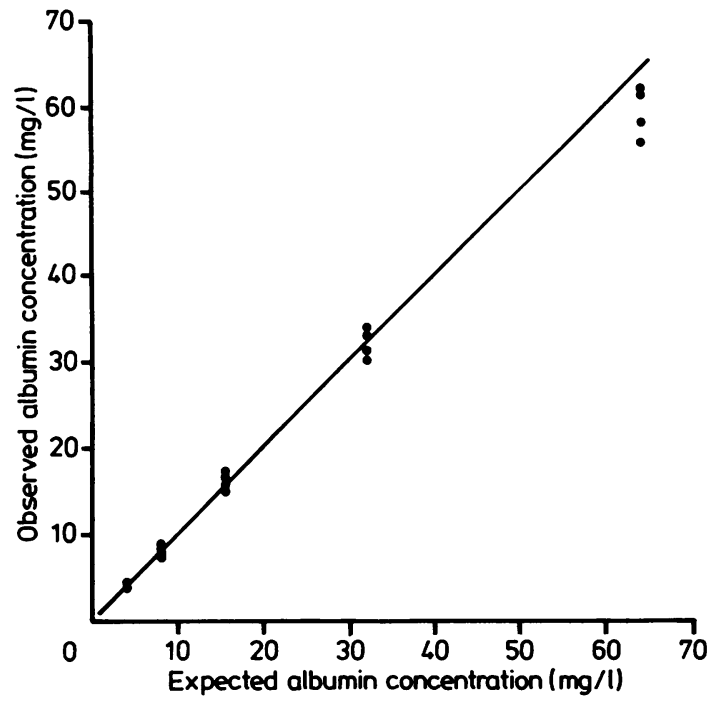

Fig 1 Albumin recoverability plot (radioimmunoassay).

METHODS COMPARISON (TABLE 4; FIG 2)

Figure 2 illustrates that the absolute variance between radioimmunoassay and radial immunodiffusion increased with the size of the reading $(\mathrm{mg} / \mathrm{l})$. Table 4 shows the mean differences between methods and the
Table 4 Comparison of urinary albumin concentration $\left(U_{A} ; m g / l\right)$ determined by radioimmunoassay and radial immunodiffusion

\begin{tabular}{|c|c|c|}
\hline & $\begin{array}{l}\text { Mean difference } \\
\text { between methods } \\
(\mathrm{mg} / \mathrm{l})\end{array}$ & $\begin{array}{l}\text { Residual standard } \\
\text { deviation } \\
(\mathrm{mg} / \mathrm{l})\end{array}$ \\
\hline $\begin{array}{l}\text { All samples }(n=64) \\
\text { Mean } U_{A} \leqslant 30(n=21) \\
\text { Mean } U_{A}>30(n=43)\end{array}$ & $\begin{array}{l}2 \cdot 0^{*} \\
0 \cdot 3 \\
2 \cdot 9^{*}\end{array}$ & $\begin{array}{l}4 \cdot 6 \\
2 \cdot 2 \\
5 \cdot 3\end{array}$ \\
\hline
\end{tabular}

${ }^{*} \mathrm{p}<0.01$ by paired $t$ test.

intramethod standard deviation. Overall, the radioimmunoassay gave consistently higher readings, but this only reached significance at albumin concentrations $>30 \mathrm{mg} / \mathrm{l}$. The random variation between methods was also greater above $30 \mathrm{mg} / \mathrm{l}$.

PRACTICABILITY (TABLE 2)

Technical skill required and turnaround time $/ 100$ tests were considerably lower with radioimmunoassay than with radial immunodiffusion. Running cost $/ 100$ tests, however, and capital costs were considerably higher with radioimmunoassay than with radial immunodiffusion, the major capital expenditure with the radioimmunoassay kit being due to the radioactive counting system. The capital cost of radial

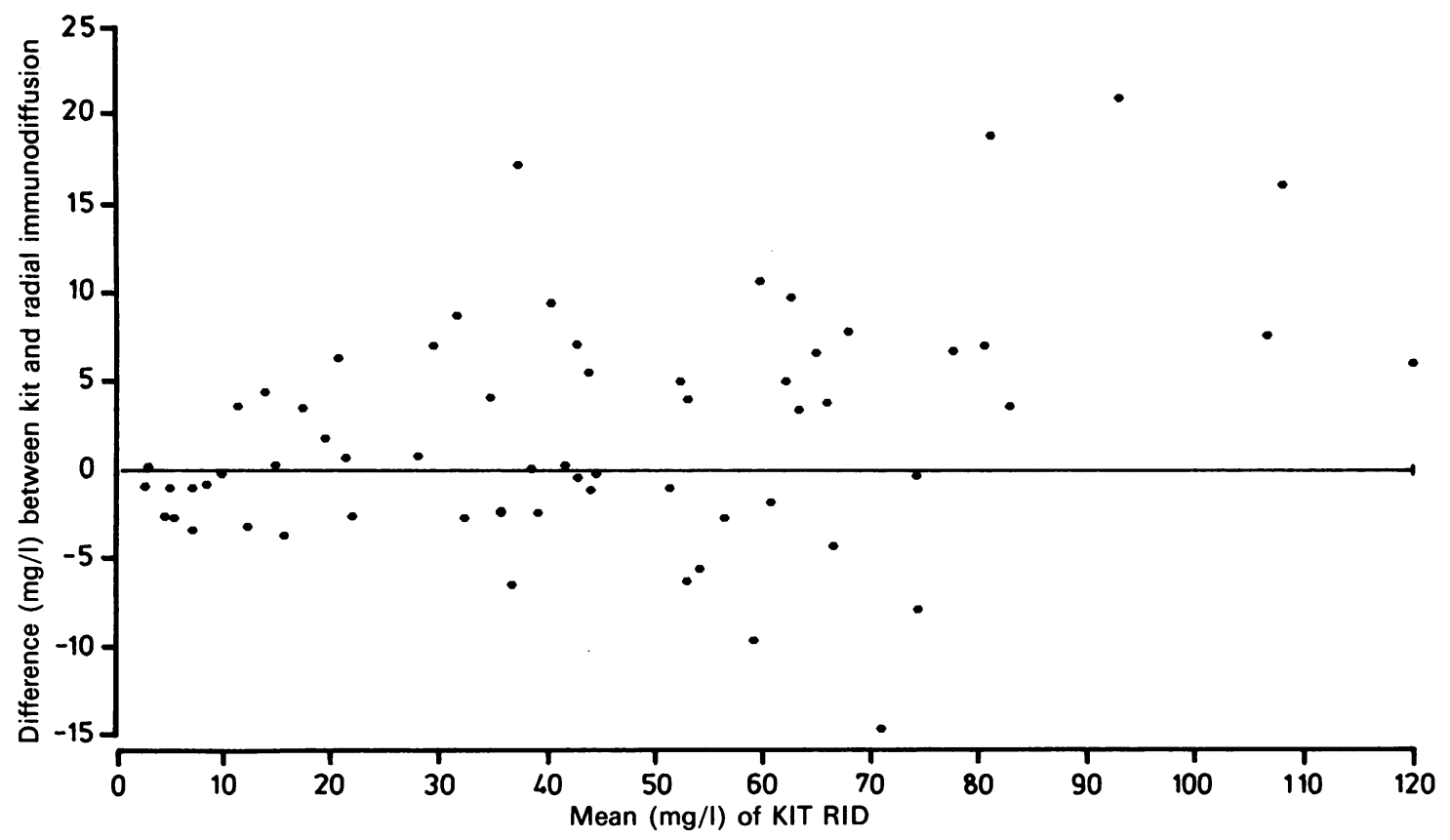

Fig 2 Measurement of urinary albumin by radioimmunoassay kit (KIT) compared with that of radial immunodiffusion (RID). 
immunodiffusion was almost exclusively due to the Rotart Vacuum Pump (RE2) (Single Stage, Baird and Tatlock, Romford, Essex, United Kingdom) used for creating wells in the agar gel plate.

\section{Discussion}

In the three studies showing that microalbuminuria is a predictor of diabetic nephropathy the urinary albumin excretion rate $\left(\mathrm{U}_{\mathrm{A}} \mathrm{V}\right)$ was greater than $15 \mu \mathrm{g} /$ minute. $^{2-4}$ To detect these values of $\mathrm{U}_{\mathrm{A}} \mathrm{V}$ at high urine flow rates $(\mathrm{V})$ an assay should be sensitive down to a urine albumin concentration $\left(U_{A}\right)$ of about $3 \mathrm{mg} / \mathrm{l}$. The assay could be required to cover the range of normal values in non-diabetic patients. Based on 30 subjects our normal values for overnight urine samples using radial immunodiffusion were: mean $\mathrm{U}_{\mathbf{A}}$ $=9.1 \mathrm{mg} / 1$ (range 2.4-22.8); mean $\mathrm{U}_{\mathrm{A}} \mathrm{V}=$ $6 \cdot 2 \mu \mathrm{g} /$ minute (range $1 \cdot 6-10 \cdot 8$ ).

We feel, therefore, that the assay characteristics make the kit suitable for screening patients for microalbuminuria. Its interassay imprecision above about $40 \mathrm{mg} / \mathrm{l}$ requires a sample predilution step when serially monitoring microalbuminuria above this concentration. Predilution is not required with radial immunodiffusion up to a $U_{A}$ of $80 \mathrm{mg} / \mathrm{l}$. Below $30 \mathrm{mg} / \mathrm{l}$ the results obtained using the radioimmunoassay compared sufficiently closely for clinical purposes with those obtained by radial immunodiffusion. Above this level the difference between methods was substantially greater, but not so great that patients would be likely to be falsely classified as positive or negative for microalbuminuria.

If a laboratory wishes to provide clinicians with an assay for microalbuminuria the choice between the radioimmunoassay kit and radial immunodiffusion will also depend on the practicability criteria that were assessed in this study. Here the main advantage of the radioimmunoassay is the lesser degree of skill required. Its running cost is high and may be further increased if the demand for the test is too small to make optimal use of the eight week shelf life of the label. The apparently high capital cost is accounted for by isotope counting equipment and may, therefore, be eliminated in a laboratory in which this is available. The advantage of a short turnaround time will probably be regarded as unimportant for a test whose results rarely need to be acted on urgently.

\section{References}

1 Deckert J, Poulsen JE, Larsen M. Prognosis of diabetics with $\overrightarrow{\vec{\omega}}$ diabetes onset before the age of thirty one. Diabetologia 1978; 14:363-70.

2 Viberti GC, Hill RD, Jarrett RJ, et al. Microalbuminuria as a predictor of clinical nephropathy in insulin-dependent diabetes mellitus. Lancet 1982;i:1430-2.

3 Mathiesen ER, Oxenbøll B, Johansen K, et al. Incipient nephro- $\vec{O}$ pathy in type I (insulin-dependent) diabetes. Diabetologia $\overrightarrow{\vec{C}}$ 1984;26:406-10.

4 Mogensen CE, Christensen CK. Predicting diabetic nephropathy in insulin-dependent patients. $N$ Engl J Med 1984;311:89-93. 으

5 Viberti GC, Pickup JC, Jarrett RJ, Keen H. Effect of control of blood glucose on urinary excretion of albumin and $O$ $\beta_{2}$-microglobulin in insulin-dependent diabetes. $N$ Engl J Med 1979;300:638-41.

6 Pedersen EB, Mogensen CE. Effect of anti-hypertensive treat- $\mathbb{D}$ ment on urinary albumin excretion, glomerular filtration rate, $?$ and renal plasma flow in patients with essential hypertension. $\overrightarrow{0}$ Scand J Clin Invest 1976;36:231-7.

7 Mancini G, Carbonara AO, Heremans JF. Immunochemia quantitation of antigens by single radial immuno-diffusion: Immunochemistry 1965;2:235-54.

8 Watts GF, Hewitt K, Bennett JE, et al. A comparison of immünochemical methods for the determination of urinary albumin at low concentrations. Diabetic Medicine 1985;2(4):310A.

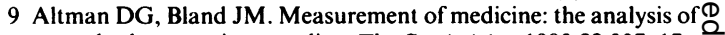
method comparison studies. The Statistician 1983;32:307-17.

10 Armitage P. Statistical methods in medical research. Oxford:음 Blackwell Scientific Publications, 1971:198-200.

11 Mogensen CE. Microalbuminuria predicts clinical proteinuria $\vec{\partial}$ and early mortality in maturity-onset diabetics. $N$ Engl $J$ Medo 1984;310:356-60.

Requests for reprints to: Dr GF Watts, Department of Chemical Pathology and Metabolic Disorders, St Thomas's Hospital, London SE1 7EH, England. 